ISBN 978-93-86878-09-0

11th International Conference on Management, Law, Economics and Interdisciplinary Studies (MLEIS-18)

Bali (Indonesia) Jan. 12-13, 2018

\title{
Tourism Marketing and Destination Management
}

\author{
Assist. Prof. Dr. Vudhayaraju. Varija, Assist. Prof. Dr. Vellore. Ramabrahmam and \\ Dr. Yadava Raghu Academic Consultant \\ Dept. of. History \& Archaeology, Yogi Vemana University, Vemanapuram. Kadapa, \\ Y.S.R. Dist, Andhra Pradesh, India \\ (Cell: +91 9963037305, Email: varijarao2009@gmail.com, ram.vellore@ gmail.com, \\ raghuyadav.history@ gmail.com)
}

\begin{abstract}
Tourism is a very complex industry because of its multi-faceted activities which together produce the 'tourist product'. Marketing is a process through which individuals and groups provide, exchange and obtain products - ideas, goods and services - capable of satisfying customers' needs and desires at a desirable price and place. Marketing requires a strategy. It is an all-encompassing, planning, scheduling, studying, figuringstuff-out, researching, testing, and practicing strategy.

Destinations are places that attract visitors for a temporary stay, and range from continents to countries to states and provinces, to cities, to villages, to purpose built resort areas. At the foundation level, destinations are essentially communities based on local government boundaries. Tourists travel to destinations. Destinations are places with some form of actual or perceived boundary, such as the physical boundary of an island, political boundaries, or even market-created boundaries.
\end{abstract}

Keywords: Tourism, Marketing, Destination, Management

\section{Introduction}

Tourism has become the world's largest industry, generating wealth and employment, opening the minds of both visitors and the visited to different ways of life. India has strong signs of becoming one of the emerging giants in world tourism. The most imperative factors for successful tourism development include product enhancement, marketing, regulations and human resource development. India's tourism is one of the flourishing sectors in terms of its scope. Tourism in India is growing continuously to generate employment and earn large amount of foreign exchange in order to stabilise the country's economic and social development. It also helps in preserving and sustaining the diversity of the India's natural and cultural environments. We should develop tourism industry with government supports, new initiations, actions and plans to influence foreigners to sustain our position strongly. Tourism in India is a key growth driver and a significant.

India holds immense potential in adventure and cruise tourism. India's greatest adventure tourism assets are Himalayas and its mighty rivers. The peak period for adventure tourism is the "lean period" of cultural tourism. Development of adventure tourism can make India a round-the-year tourist destination. The cruise industry is one of the most promising industries in India. However, strong efforts need to be made to develop this industry. Other forms of tourism such as agric tourism, pilgrimage tourism, heritage tourism, and MICE tourism also hold enormous potential. Prospects in Tourism Industry Healthy economic growth recorded in past few years, especially in the services industry, have led to increase in business travel. Higher disposable income and affordability have increased domestic leisure travel in India. Foreign tourist arrivals in India have also grown. 
However, the industry has shown signs of recovery in the first half of 2010. This is a clear indicator that the long-term prospects for the Indian travel and tourism industry are bright. India is expected to witness increased tourist activity both in the business and leisure segments in the coming years. India has been identified as one of the fastest-growing countries in terms of tourism demand.

Marketing and Promotion India needs to change its traditional marketing approach to a more competitive and modern approach. There is a need to develop a unique market position and the brand positioning will be the essence of the country's tourism products to the potential customer. Indian tourism products are promoted primarily by the Ministry of Tourism with the involvement of state governments through the State Tourism Development Corporations.

Asian countries also demonstrate strong skills in online marketing - especially in countries such as Malaysia and Turkey where Internet penetration are increasing the most rapidly. A 2013 Phocusright study indicated that nearly one third of all travel sales are completed online, and tourism businesses are quickly adapting their models from more traditional word of mouth marketing to "electronic word of mouth", namely an increased use of social media. Southeast Asia is the most advanced sub-region within the group, supporting strong ICT infrastructure and very sophisticated destination marketing supported by engaging, experience-led content.

The Arab Group represents a broad collection of states that include the highly developed Gulf countries with newly developing destinations in North Africa. Destinations like Dubai and Egypt consistently leverage successful multi-platform marketing with a broad appeal to many international audiences, while digital marketing efforts in Mauritania and Kuwait are relatively weak. E-mail marketing is particularly popular among the Arab countries where it is believed to be a successful channel at building trust in a brand, especially when targeted. Through improving, the African group demonstrated the weakest performance in terms of all four key elements. Perceptions of the utility of social media remain low and digital literacy programming is not common in primary or secondary education - reducing the availability of skilled professionals to support tourism operations.

\subsection{What is Destination Management?}

Destination management is the coordination and integration of all of the elements of the destination mix in a particular geographic area based upon a defined tourism strategy and plan. The destination mix elements are the attractions and events, facilities (hotels, restaurants, etc.), transportation, infrastructure, and hospitality resources (Mill and Morrison, 2012). In addition, destination management encompasses the image-making, branding, and marketing and communications of all that the place has to offer to tourists.

Destination management and destination marketing are relatively new phenomena in tourism professional practice and in the tourism literature. They have now, however, become recognized as being integral to the success of a tourism destination. This article traces the history of the scholarly literature development and professional practice in destination management and destination marketing since around the 1980s. The two concepts are explained in detail, as are the roles of destination management organizations (DMOs).

\subsection{What is Destination Marketing?}

Destination marketing is one of the most important DMO roles. So the planning of destination marketing takes on a high priority for a DMO and destination marketing planning must be done professionally and thoroughly. Marketing and promotions are expensive so making the right choices of which markets to target and how to communicate the most effectively are of paramount importance.

Destination marketing planning must not be haphazard, but requires a systematic, step-by-step approach. The destination marketing planning process is one template that can be used. Every DMO 
needs to plan its destination marketing and it is very important to think of this planning as consisting of long-term (strategic) and short-term (tactical) time dimensions. For destination marketing, the strategic dimension is defined as three to five years into the future, while the tactical dimension is one to two years ahead. A core part of the destination marketing planning process is the creation of a time-ordered hierarchy of marketing goals and objectives.

\section{Methodology}

This study focused on gaining in-depth insights into the nature and scope of stakeholder involvement and participation in the strategic marketing planning process within the tourism industry in Northern Ireland. A qualitative, in-depth research approach was chosen to provide insights into the various perspectives of stakeholders involved in the tourism industry in the context within which they operate and to achieve a rich and in-depth account of the level of stakeholder involvement in strategic marketing planning.

\subsection{The objectives and descriptors of Paper}

The aim of this papers to provide the principles of tourism destination marketing. Tourism and moreover Business tourism does not exist in a vacuum. It can only function if it shares, cooperates and dialogues effectively with many other sectors of society and economy.

The paper also explains that marketing of destinations should balance the strategic objectives of all stakeholders as well the sustainability of local resources. Destinations need to differentiate their products and develop partnerships between the public and private sector in order to co-ordinate delivery. Destination marketing must lead to the optimisation of tourism impacts and the achievement of the strategic objectives for all stakeholders. Taking advantage of new technologies and the internet also enables destinations to enhance their competitiveness by increasing their visibility, reducing costs and enhancing local cooperation.

Following main issues are dealt with in this course:

1. Introducing destinations and destinations marketing

2. Destinations - an amalgam of tourism services and experiences

3. The importance and the critical roles played by the DMO (Destination Management Organization) in the tourism policy development and implementation.

4. The strategic purpose of destinations and their management and marketing

5. Main markets and destination choice

6. Types of destinations, target markets and marketing strategies required

7. Marketing research: identifying market segments for destination products

8. Marketing destinations: strategies and practices

9. Destination marketing mix: formulating the destination product, pricing the destination, distributing tourism destinations, promoting the destination.

10. Destination Branding

11. Destination Image

12. Destination positioning in the marketplace.

\section{Literature Review}

These principles can be applied to the tourism system context, which is pressured into more collaboration, particularly in the planning and marketing areas. Bramwell and Sharman (1999) identify 
three potential benefits deriving from consensus-based collaboration. First, it may avoid the costs of solving conflicts among stakeholders (Healey, 1996). Second, it may legitimate collective actions if stakeholders are involved in the decision-making processes which affect their activities (Benveniste, 1989). Third, the willingness to collaborate may enhance the coordination of policies and related activities. Their argument is underpinned by stakeholder theory, which was pioneered by Freeman (1984), who defines as a stakeholder "any group or individual who can affect or is affected by the achievement of the organization's objectives".

\section{Theoretical Background}

DMOs are the organizations responsible for management and/or marketing of destinations and generally fall in one of the following categories (World Tourism Organization, 2004): national tourism agencies or organizations (NTA or NTO), regional or provincial organizations and local organizations. According to Buhalis (2000, pp. 109) "DMOs have an overall responsibility for the entire destination product and through incentives and policies facilitate the development of products, which is desirable from the demand side, and at the same time does not jeopardize local resources".

In destination management DMO must play a more active role in winning increasingly demanding and experienced consumers where ICT play a major role (Buhalis \& Egger, 2008; King, 2002; Petti \& Passiante, 2009; Wang, 2008). The new realities in tourism distribution prompted by advances in technologies and the new demanding consumers require a different market approach.

\section{Conclusion}

Destination management and destination marketing have become "mainstream" topics in the tourism research literature since the year 2000. Today these two concepts are also integral to professional practice in tourism destinations; they now represent the platform for achieving excellence in tourism destinations. It is especially important that destination management organizations (DMOs) perform all of their roles with balanced intensity and that a systematic and research-based marketing planning process be followed.

Although destination marketing in Western countries has progressed rapidly in the past 25 years, DMOs in Mainland China are yet to implement state-of-the-art professional practices in both destination marketing and destination management. This article has identified 15 specific improvements that are required in China in these practices. Chinese scholars should play a role in advancing these professional practices in China by focusing more of their research on the topics of destination management and destination marketing.

Tourism destinations are probably one of the most difficult "products" to market, involving large numbers of stakeholders and a brand image over which a destination marketing manager typically has very little control. The diversity and complexity of tourism destinations is well documented and this makes brand development very difficult for national, regional and local tourism organisations. Destination branding necessarily involves the focused attention of all tourism-related organisations in a destination, and this can create major challenges in getting all stakeholders to develop a coherent theme for the destination brand.

Only those destinations that have a clear market position and appealing attractions will remain at the top of consumer minds when they book their holidays. In the highly competitive and dynamic global tourism environment, there is a need to develop a clear identity, or "brand" based on reality, while also reflecting the core strengths and "personality" of its product. In this crowded marketplace, building and maintaining brand value is the key to business success and, as a result, brand management is quickly shifting from a peripheral marketing concern to the core business strategy. 
This is a reason for including The Tourism Destination Marketing in curricula for the students in the field of tourism.

\section{References}

[1] Ashworth, G. J. and Goodal, B. (eds) (1995), Marketing tourism places, New York: Routledge. Ritchie \& Zins, 1978.

[2] Blumberg, K (2005), Tourism destination marketing - A tool for destination management? A case study from Nelson/Tasman Region, New Zealand, Asia Pacific Journal of Tourism Research, Volume 10, Number 1, March, pp. 45-57(13)

[3] Cedefop (2005). Panorama. Trends and skill needs in tourism, Olga Strietska-Ilina, Manfred Tessaring (eds), Luxembourg: Office for Official Publications of the European Communities, p.7-12.

[4] European Commission, DG Enterprise (2001). Improving training in order to upgrade skillsin the tourism industry. Final report of Working Group B. Brussels: European Commission, p.26.

[5] Gold, J. R. and Ward, S. V. (eds) (1994), Place promotion: the use of publicity and marketing tosell towns and regions.

[6] Chichester: Wiley. Keller, K. L. (2003), Strategic brand management (2nd ed.), Upper Saddle River, Prentice-Hall.

[7] Kotler, Ph., Bowen, J., Makens, J. (2006), Marketing for hospitality and tourism, Pearson: Prentice Hall.

[8] Leiper, N. (1990), Tourist attraction system, Annals of Tourism Research, 17, 367-384.

[9] Morgan, N., Pritchard, A., Pride, R. (2004), Destination branding: Creatind the uniquedestination proposition (2nd ed.), Oxford: Butterworth-Heinemann.

[10] Pearce, D. (1992), Tourist organisations, New York: Wiley.

[11] Pike, S. (2004), Destination marketing organisations, Advances in Tourism Research, Elsevier.

[12] Ries, A. \& Trout, J. (1982), Positioning: The battle for your mind, New York: McGraw-Hill.

[13] Ritchie, J. R. B. \& Crouch, G. I. (2003), The competitive destination: A sustainable tourismperspective, Oxon: CABI Publishing. 